\title{
The International Program Perspective: The Education of Gifted Children in Malta'
}

\author{
JOAN BORG MARKS \\ UNIVERSITY JUNIOR COLLEGE \\ MSIDA, MALTA
}

\begin{abstract}
Education is all about making provisions for individual differences and specific needs. All students, including the gifted, need their fair share of care. However, very often, gifted students are neglected because many believe that they can manage on their own. Brain power alone is not enough for the realization of giftedness. Perseverance, creativity, motivation, self-esteem, and the potential for high ability are ingredients that only when blended together lead to high achievement. This article looks at the important events in the history of education in Malta that could have had effects on the education of its gifted students. Malta's educational structure is also outlined. Some major policies and practices within the educational system are examined to assess how effectively Malta provides for the educational needs of gifted students. Although it is evident that Malta hardly acknowledges the gifted, there have been encouraging recent educational developments in the country that promise a brighter future for all students, including the gifted.
\end{abstract}

\section{Introduction}

All over the world and since the beginning of time, people have been interested in men and women who have exhibited superior ability. Everyone is aware of the existence of individual differences. Different individuals show diverse interests, diverse capabilities, and diverse potential, as well as diverse drives for achievement. In education, individual differences are an accepted fact, but the question is, how well do educators make provisions for them? Although considerable pressure is often exerted toward improving the conditions for the lower ability group - something which is not being argued against, of course - the issue regarding improving conditions for students of high ability is often treated at a very different level. The gifted are indeed often neglected because many people believe that they can succeed on their own. The existence of gifted

\footnotetext{
${ }^{1}$ Ms. Sandra Dingli, coordinator of the Creative Thinking Program at the University of Malta; Prof. Edward de Bono; Mr. Frank Mallia, Education Officer Special Needs within the Malta Education Division; and Mr. Charles Mizzi, Director General of Education, are duly thanked for their patience and cooperation in allowing the author to interview them during the research conducted in the preparation of this paper.
}

underachievers (George, 1995, p. 11; Young \& Tyre, 1992, p. 19) is an indication that the gifted do need their fair share of attention in schools.

Although the early literature on giftedness focused more on genius and eminence and the conditions that created them (Terman, 1926), more recent conceptions have tended toward a multidimensional view of giftedness. Apart from the fact that it is accepted that an individual can be gifted in a specific domain or across many talent domains (Gardner, 1983), it is also certain that for the expression of giftedness to occur, aspects of motivation, self-esteem, perseverance, creativity and intellectual factors are all involved (Sternberg \& Davidson, 1986).

Brain power, alone, is not enough for the realization of exceptional performance. "Without the support of nonintellectual traits, such as the capacity and willingness to work hard in achieving excellence, it is impossible to rise above mediocrity" (Tannenbaum, 1986, p. 31). Modern concepts of giftedness emphasize this interaction of intellectual and nonintellectual factors, thereby helping to establish appropriate paths to excellence in particular fields of endeavor (Renzulli, 1986; Montgomery, 1996). 
In Malta, the policy has always been to try and offer the best education to all students. This article considered whether Malta has taken up the challenge of creating an educational experience within its schools that makes provisions for and promotes the holistic development of gifted children.

\section{Education in Malta - An Historical Perspective}

An historical glance at some of the relevant issues in the development of education in Malta shows that the first government-supported school was already in existence in 1397 (Zammit Ciantar, 1993). It was, however, only in the early 1800 s that the start of a movement toward the education of the masses could be witnessed.

In 1836, when Malta was under British rule, a Royal Commission was appointed to inquire about the state of affairs in Malta. Only three governmentsupported schools were in existence and the education observed was "small in quantity and bad in quality" (Austin \& Lewis, 1838 and Lawson, 1838, as cited in Sultana, 1997, p. 61). "By 1842, Malta could boast of 19 elementary schools catering for 1,296 students, and 135 private schools for 2,218 fee-paying pupils (Blouet, 1989, as cited in Sultana, 1997, p. 61). But thousands of students went without an elementary education right up to 1946 when finally a free and compulsory primary schooling law was enacted" (Sultana, 1997, pp. 61-62). This rather late development with regard to Malta's elementary educational services is historically explained in terms of the fears of influential citizens within the clericoprofessional sector, the elite, and the privileged and the professional classes, who saw an educated people as a threat to their old privileges.

Certainly until the present time, attention to the educational needs of the gifted in Malta was nowhere on the agenda. As more and more students gained access to education, the tradition of having schools exclusively for the elite became even further entrenched - a tradition that has persisted through the ages (Sultana, 1997).

After the first quarter of the twentieth century, attention turned to diversifying educational provisions. A.V. Laferla, then Director of Education, was influenced by the British Hadow Report of 1926, which had proposed the division of children on the grounds of ability and the diversification of curriculum, depending on the pupils' achievement and orientation. Further reforms were also introduced. These concentrated on the gender issue and on providing technical education for boys and domestic education for girls (Sultana, 1996; Sultana, 1997). "The 1930s indeed saw the restructuring of education away from the common, inclusive provision in the State sector, to a differentiated one which set the foundation for the inter- and intra-school streaming practices that mark our educational system today" (Sultana, 1997, p. 78).

Until 1970, secondary education was ultraselective. Maltese students could gain access to secondary education after passing the $11+$ examination or by enrolling in a fee-paying private school (Buhagiar, 1998). In 1970, with the introduction of secondary education for all, teachers started teaching with examinations in mind, preparing all students for the General Certificate of Education (GCE) examinations set by British universities. In 1972, comprehensive education was introduced in government schools, and a system of continuous assessment substituted the formal end-of-year tests that used to determine promotion from one year to the next. However, the end-of-year examinations were reintroduced in 1973 and 1974 when problems were being encountered with comprehensive education.

"The pretence of having a comprehensive system in State schools with an undifferentiated curriculum was kept for another four years" (Ventura, 1996 , p. 168). In 1978 and 1979, students were again differentiated by aptitude and were offered a different curriculum. A Special Science Examination was also conducted in 1978 and 1979 for students in Form 3 (13 to 14 year olds) of government secondary schools. "The purpose of the examination" was "to select students for the special classes in science subjects at the science centres" (Education Department Circular, May 29, 1978, as cited in Musumeci, 1981, p. 1). From 1981 onward, examinations in Maltese, English, and mathematics were set in order to select the top achievers who were then directed to Junior Lyceums (schools equivalent to British grammar schools), where they were to be provided with accelerated education for students with high intellectual abilities (Ventura, 1996).

Even though this last series of events seemed 
to favor the gifted, an educational system characterized by sudden and sweeping changes and in which reforms have traditionally lacked researchbased, broad-based, and grass-roots consultations (Wain, 1994) could certainly not yet be prepared to offer quality education to all students, irrespective of their potential and learning style.

\section{The Educational Structure in Malta}

Human resources are by far Malta's principal resource. In spite of its small size and relatively small financial investment in education, Malta strives to provide the best possible educational services. "During the last half century, the educational system has expanded at an extremely rapid rate so that Maltese students benefit from a wide spectrum of schooling provisions" (Farrugia, 1991, p. 17) (see Figure 1).

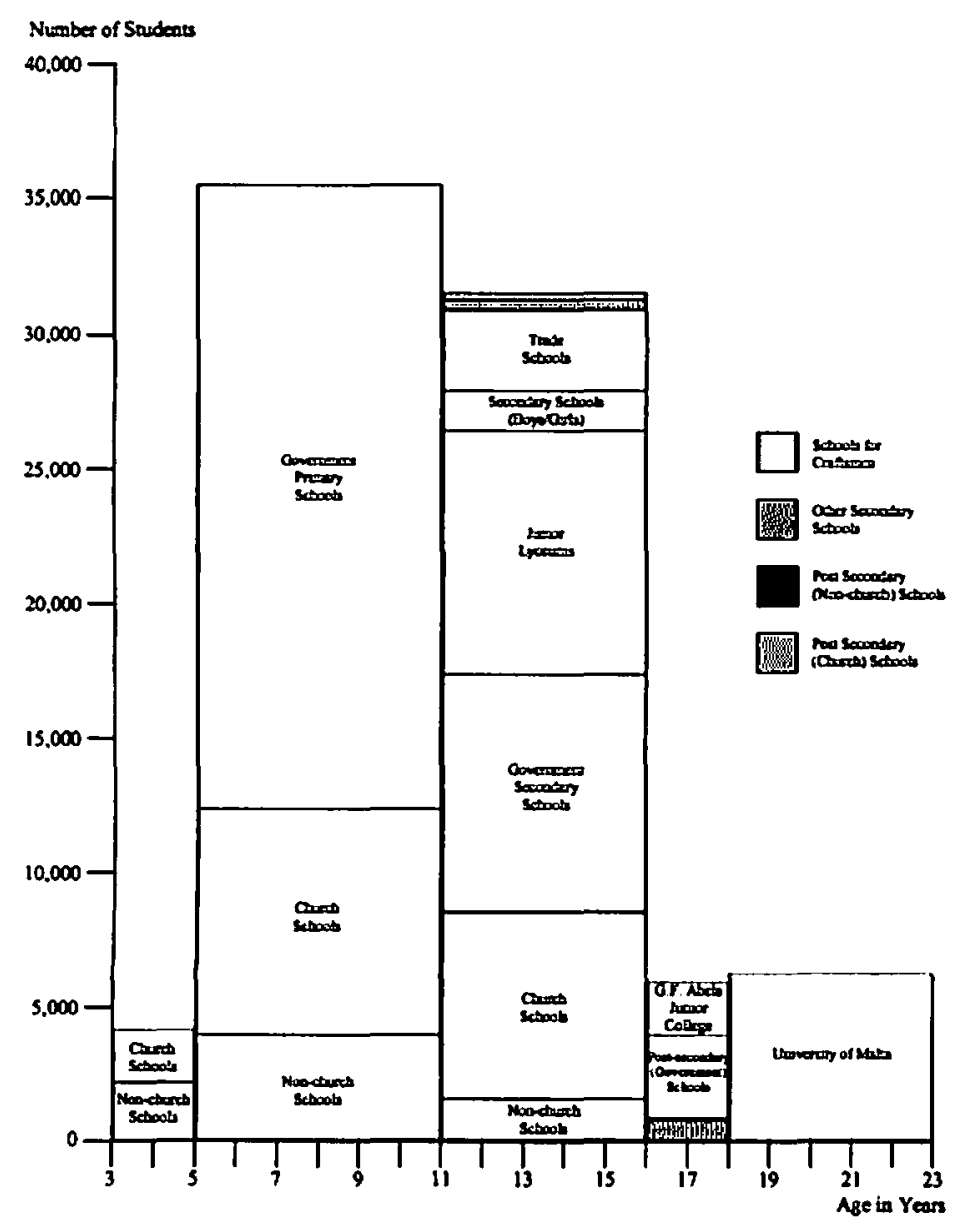

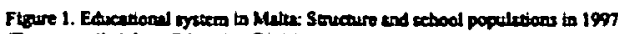
(Dira cospiled tors Education Diviston)
Education in Malta is compulsory between the ages of 5 and 16. The government provides education that is completely free in all its institutions, including free textbooks and school transport at the primary and secondary school levels, as well as study allowances to students in postsecondary education. There are also private schools, providing mainly for students within the compulsory school age bracket. The latter, however, do not provide any form of technical education (Zammit Ciantar, 1993).

Kindergarten is available for children who have reached the age of 3 years. At this age, emphasis is on the socialization of the child. The opportunity for guided intellectual, emotional, and physical development is also encouraged (National Minimum Curriculum Regulations, 1989, Primary Level; National Minimum Curriculum, 1999). Primary education lasts for 6 years. At the end of this stage, students sit for a qualifying End of Primary National Examination (the 11+ examination), which takes them to their secondary stage of schooling, lasting for 5 years and ending with the $16+$ examinations.

The government also provides education at the postsecondary level for students who satisfy the minimum entry requirements. A University Junior College was established in September 1995 to provide more specifically for those students who intend to go to university. A number of private schools also provide university entrance courses. These courses are of a two-year duration, at the end of which the students are examined in two subjects of their choice at $A$ (the highest level) and in three subjects of their choice at an intermediate level. Another subject, Systems of Knowledge, is taken at the intermediate level, and it is compulsory. Success in these examinations entitles the student to a matriculation certificate, which then ensures entry into the University of Malta (University Information Booklet, 1994), subject to the condition that the specific entry requirements of the particular course chosen are fulfilled. Education at the university level is free of charge for Maltese nationals.

Looking at Malta's educational system globally, one might say that it offers the perfect setting for the growth of the gifted child. Some characteristics of the system, namely, an early school start (therefore, early reading and writing) and a free higher education, are amongst the characteristics that 
Freeman (1992) describes as well-suited for the gifted. Furthermore, one cannot but be impressed at how the Education Act of 1988 (Malta Government, 1989 , p. A277) emphasizes "the duty of the state to promote education and instruction and to ensure the existence of a system of schools and institutions accessible to all Maltese citizens catering for the full development of the whole personality..... and to provide for such schools and institutions where these do not exist." Such emphasis might well be taken as an indication of the possible existence of the provision of a suitable education for the gifted in Malta. When one considers the details, however, one might argue differently.

\section{Providing for the Needs of the Gifted}

As part of the research undertaken for this study, the author interviewed a number of people, one of whom was the Education Officer of Special Needs. During this interview, the officer confirmed that unfortunately the gifted in Malta seem to have been somewhat abandoned. In the primary years, and at teachers' discretion, enrichment cards may be used, covering work above what one teaches to the rest of the group. In the secondary school, "hopefully, maybe they can take care of themselves" (F. Mallia, personal communication, October 1997). No pressure groups have ever pushed forward the idea of helping the gifted. Thus no one specifically provides for their educational needs. The focus is on children who find difficulty coping with basic educational requirements. No comments have reached the Malta Education Department regarding children who are not being intellectually challenged. Parents are usually aware that they have a brilliant child, but if he or she is passing his or her examinations, the parents seem satisfied, regardless of whether the child is underachieving.

\section{The Introduction of the National Minimum Curriculum}

The Maltese educational system did, for many years, lack a formal, comprehensive, and holistic curriculum. The Education Act of 1988 (Malta Government, 1989) was a legislative attempt to fill this void (Farrugia, 1991). With this act, came the introduction of the first National Minimum Curriculum (NMC), which was a new feature in Maltese education, trying to ensure that a minimum education be guaranteed to all children.

This NMC, however, did not have an optimal effect in schools. It "neglected the fact that the quality and rate of learning depend on the ability of the learner and that educational programs must be organized so as to take into account the wide range of differences in the productive behavior between children" (Mifsud, 1991, p. 55). Moreover, with an overloaded curriculum, the chance for able children to develop quality and depth in their thinking was, and still is, rare.

"Malta is entrenched in a highly centralized and bureaucratic system (although a wind of change is blowing in the opposite direction)" (Bezzina, 1997, p. 16). One predominant feature of the Maltese system that seems to have had negative effects, especially on the learner, is the fact that up to the scholastic year ending July 2000, national examinations were set for each year, from primary to secondary level, and it was the results of these examinations that were used as the only criteria for promotion, selection, and streaming. For the sake of clarity, streaming is that type of "school organizational policy whereby children are grouped into classes of homogeneous ability. Assignment to classes is based on scholastic attainment (usually in terms of performance in a number of examinable curricular subjects), and/or mental ability (that is on the basis of performance on intelligence tests)" (Borg \& Falzon, 1989, p. 15). This has forced parents, students, and teachers to become too exam conscious to the extent that it may be said that "in Maita, examinations set the pace, dictate the form and nature of the learning content and teaching methods" (Farrugia, 1991, p. 24). Another group has noted that "Schools resemble rather more sorting and channeling mechanisms than communities where meaningful learning takes place" (Consultative Committee on Education, 1995, p. 17). More has been said specifically regarding the gifted, namely that the system "encourages them to remain within the narrow confines of exam-oriented learning and all that it entails - including excessive stress, an approach which privileges extrinsic rewards such as grades rather than intrinsic satisfaction of learning, the stunting of the development of wider aspects of one's 
abilities and one's personality" (Consultative Committee on Education, p. 18).

With reference to private schools, while the impact of exams may be less drastic since "both students and teachers are not consistently assailed by perceptions of 'being caught napping' by examination questions prepared by some unknown individual at the Head Office," (Buhagiar, 1998, p. 9), yet they still have to deal with external $16+$ and $18+$ examinations in the same way as government schools. Indeed, "some primary private schools do not differ much from the State ones. Teaching in private schools with no secondary classes, at least towards the end of the primary cycle, gets equally caught up in the $11+$ exams preparation mania" (Buhagiar, 1998, p. 9).

The first NMC (1989 - 1990) recommended the following: (a) teaching methods "that stimulate reactions from the child, which rely on problem solving" (NMC Regulations, 1989, Primary Level, p. B 385), (b) tests and examinations which "should not be allowed to train children in sheer memorization and cramming of what they have been taught" (NMC Regulations, 1989, Primary Level, p. B 385), and (c) the training of students "in the process of self-learning and self-education" and the use of "research methods and problem solving" leading to conclusions and solutions, (NMC Regulations, 1990, Secondary Level, p. B 588). What actually happened, however, was quite different.

\section{Selection and Streaming}

In Maltese government schools, there has been a strong emphasis on streaming in past years. The method of selection based on national examinations has been playing havoc on all Maltese students. It resulted in "an educational process which discourages co-operation between students and emphasizes individual competition" (Mifsud, 1997, p. 20).

Both locally and abroad, the system of streaming is considered a very unjust system because pupils were streamed solely on the basis of end-ofyear examinations. Yet in Malta, "many practitioners are themselves in favour of it" (Darmanin, 1985, as cited in Sultana, 1989, p. 13). Maybe this is because teachers feel they lack the skills required to teach a mixed-ability class. "For control reasons too, teachers might prefer to have a class progressing at the same pace so that orchestration of tasks commences and terminates roughly at the same time for all" (Sultana, 1989, p. 13).

In a study on Maltese students, Borg and Falzon (1989) have confirmed the following shortcomings involved with the practice of streaming: (a) streaming favors older children; (b) there is an element of sex bias in stream placement, with more girls than boys in the $A$ stream (the classes in which the pupils with the best marks obtained in the end-ofyear tests are placed) and vice versa for the $C$ stream (the lower ability classes); (c) the validity and reliability of the criteria on which streaming is based are suspect; and (d) teachers' attitudes and expectations are modified by the ability stream they teach, to the detriment of the learner Borg and Falzon (1989) in fact recommended alternatives to streaming, namely either:

- horizontal setting, which "is the division of pupils of a particular year group into sets according to ability in particular subjects" (Page \& Thomas, 1977, as cited in Borg \& Falzon, 1989 , p. 19). A student may be, for example, in the top set for English and in the bottom one for mathematics, but returns to his/her normal mixed-ability class for the remaining curricular subjects; or

- vertical setting, where "instead of organising the sets in one year group only, the sets cut across several year groups" (Borg \& Falzon, 1989, p. 19); or

- topping and tailing, whereby the averageability students are divided into mixed-ability classes, while the gifted and the most able at the top end and the slow learners at the tail end of the distribution are withdrawn for one or more subjects ? the top end for enrichment and the tail end for remedial teaching (Borg \& Falzon, 1989).

However, Borg and Falzon (1989) believed that perhaps horizontal setting was the most attractive of the alternatives. Hirst (1989) also advocated that in providing opportunities for the fullest possible fulfillment of one's abilities, one must point to ability grouping "though setting for specified areas, rather than streaming, would be ideal" (p. 6).

Indeed, one has to realize that although 
streaming will hasten the general pace of the lessons, there might be some students for whom further challenges are required. Darmanin (1996) believed that educators must recognize differences between students and "ensure that those most in need will receive enhanced educative experiences whilst in the meantime entitlement of 'less' needy students should also be protected or addressed in ways which it has not been so far" (p. 77).

\section{The Department of Curriculum Development}

In May 1995, a new Department of Curriculum Development within the Education Division was established with its own Director of Curriculum Development. It seems that since that time, Maltese education has taken a turn in the right direction. The author has had the opportunity to interview the director of this department on two occasions, once in September 1996 and again in June 1997.

One of the aims of this department is to make one continuous process of primary and secondary education. In the revision of the curriculum, which has been given priority on the educational agenda during the last 5 years, the director did not want to make decisions single-handedly. A team of two assistant directors and 25 education officers worked together and with the schools concerned, with the aim of concentrating more on what was and what should have been happening in the various schools with the aim of improving the outcomes in actual classrooms. It was deemed necessary to try and go beyond syllabi and try to find ways of reaching all students, providing for their needs, and thus helping them in developing a positive measure of self-esteem by the end of their school years.

The mission statement of the department, We are committing ourselves to promoting quality learning in Maltese education, has vast implications. The director said, however, that one goal at the top of the list is to help all involved to distinguish between an environment of instruction and one of selfimprovement and self-learning - a condition which will certainly be much to the advantage of all students, including the gifted.

Although the director seemed more aware of the needs of the lower ability stream, he did realize that even the gifted may become frustrated in an educational system like Malta's, where, as he said, "teachers have become 'drill sergeants' and have converted examinations into 'a pack of notes'!" (C. Mizzi, personal communication, September 1996)

With regard to streaming versus setting, the director felt that in government schools, setting is one of the long-term objectives. Indeed, there could already be setting in some schools, but as yet this is not the general policy.

In the last 10 years, the need for overall educational reform has forced Maltese educators to look hard at the subject of education, but the climate of change is starting to produce a different educational system. The end product will hopefully look considerably more at individual children and their specific needs.

\section{The Issue of Creativity}

In Malta, with all the emphasis on memory work and cramming for exams, educators have tended to neglect the development of creativity in schools. On the other hand, much to Malta's good fortune, in October 1992, The Edward de Bono Program for the Design and Development of Thinking was set up. It has been surviving with success and, seems to be making the Maltese population, in general, and the education sector, in particular, more aware of the importance of creativity and thinking skills.

The author interviewed the coordinator of this program. According to her (S. Dingli, personal communication, October 1992), there are three routes by which a child might improve: (a) literacy, (b) numeracy, and (c) operacy, the skills of doing, which apply all the thinking skills - critical, analytical, and creative - together with knowledge, to the matter in hand (Maclure, 1991).

Although thinking skills as a subject is not yet part of the curriculum in primary and secondary schools, the Edward de Bono Program has embarked on projects that emphasize the importance of thinking skills. For example, units on creative thinking are delivered to undergraduates and postgraduates, making use of de Bono's methods.

Another project is Kids on Campus, a summer school in creativity for children. The school offers those who attend the opportunity to benefit from an 
environment that stimulates inquiry, explores ideas, some of which might be philosophical in nature, and promotes discussion on issues such as good and evil, friendship, love and the self, and beauty. This experience aligns with Matthew Lipman's philosophy for children (Giordmaina, 1997). Children at this summer school are also introduced to de Bono's thinking tools, which are used as required, to create new ideas and solve problems.

It is worth mentioning that, while the de Bono program is increasing in popularity in Malta, other related programs mentioned by Nisbet (1991), like Talents Unlimited, HOTS (Higher Order Thinking Skills), and Feuerstein's Instrumental Enrichment are also of interest. Additional methods concerned with the infusion of thinking through the curriculum, such as the project Cognitive Acceleration through Science Education (CASE), is already quite popular in some British schools (Nisbet, 1991). As a general rule, whichever teaching method is used, what is important is that educators give the individual student more freedom to think and to be an individual.

\section{Toward a Better Future}

There are many problems that need to be attended to in education. Malta realizes this and seems to be experiencing a climate of change. Considerable interest has arisen to include lateral thinking in schools. In September 1997, a seminar on creativity and thinking skills conducted by Prof. de Bono was organized by the Education Ministry for primary school teachers and education officers. The aim was to expose teachers to de Bono's thinking methods and have them implement the methods in their teaching ("Creativity and Thinking," 1997). Moreover, in 1998 , more training sessions on the de Bono methods were conducted for teachers (Cassar, May 29, 1999) and close to the end of the scholastic year 1998 to 1999, an event entitled Kids Can! was organized for 2,800 government primary school students. It was this event that Prof. de Bono conducted for Year 4 pupils ( 8 to 9 year olds), which was instrumental in firing the children's imagination. The aim was to show "educators how thinking skills can also become part of our own primary school national curriculum" (Cassar, 1999).

Other changes include adjustments to the primary level syllabus. Since September 1997, a midweek project ("Wanna be Creative," 1997), which introduces students to more creative activities, has been included. Also, since 1996, summer school has been organized by the Education Division. It aims at giving children more freedom for self-expression, and it allows them to look at school from a different perspective.

Additionally, to promote reading as a fascinating and exhilarating pastime, a new campaign has been launched. Let's Enjoy Reading aims to encourage the Maltese, especially those of a tender age, to read more. While a study was carried out to identify and analyze early literacy problems, book fairs and other activities have been regularly organized to spark children's interest in books. With this aim in view, 1998 was declared the "National Year of Reading" (The Newsletter of the Education Division, 1997).

Moreover, as the Ministry of Education, the University of Malta, and Rowan University have embarked on a series of joint ventures based on the Let Me Learn approach to teaching and learning ("An Ongoing," 1997; Johnston, 1997a). The hope is that in the near future Maltese educators will be able to look more at each child as an individual with his or her combination of talents, rather than as a single group in a particular stream. The Let Me Learn process, which has been described as a "straightforward approach to enhancing each student's interactive learning patterns" ("Maltese Teachers," 1998, p. 40), is being applied in three local schools in a pilot project that started in October 1998. Forty-one teachers are currently being trained in the process, and "the ultimate aim is to train as many teachers from as many schools as possible" ("Making the Most," 2000, p. 25). The mission statement of Let Me Learn is to make a difference each day, all year, one learner at a time (Johnston, 1997b). Let Me Learn will help all educators in Malta look more closely at what each child actually needs in order to move forward. Hopefully, it will help Malta focus on what is wrong with some aspects of the educational system, rather than blaming all of the system's problems on the students. An important aspect of the Let Me Learn process is that it benefits gifted students as well as students with disabilities. Learning who one is as a learner is beneficial for everyone, not just the 
remedial child. The high grades that a good student achieves are not enough. Even the best student might find problems when he or she comes in contact with the real world where no one is going to guide that person's decisions and choices.

Finally, considerable work has gone into the production of the new NMC that started the journey towards its realization (Ministry of Education, January 14,2000 ) in September 2000. In the new NMC. much reference is made to the fact that students are different and that all educators must respect this difference. The new NMC should, one hopes, provide "enough space for schools to tackle the educational realities of their students" (NMC, 1999, p. 30). The educational provision of schools is perceived as being two-pronged. Thus schools are expected to provide "a basic educational package for everyone and specialised provision catering for the particular needs of specific students" (NMC. 1999. p. 30).

\section{Recommendations and Conclusions}

It is obvious that in Malta gifted education is almost nonexistent, yet with the proposed educational changes in view and those already in effect. the position of even the gifted students is improving. Nevertheless, more can be done. Now that individual differences and specific needs of students are being given more importance. everyone needs to become more aware of the existence of gifted students so that they can be identified as early as possible. In this way, educators can focus more on the prevention of underachievement than on its remediation. It is recommended that educational authorities do their best in increasing this awareness by organizing conferences with specialist guest speakers; organizing seminars, short courses, and meetings for interested leaders, teachers, and parents; and distributing appropriate literature. Thus the problems that the gifted face may be better understood, leading to a rationale for action.

In addition, educators certainly need to become familiar with the idea that the gifted do not need more or a better treatment, but a different one, if they are to fulfill their potential. An adequate and differentiated curriculum, together with enrichment materials, should be provided. Certainly this should not be equated with privilege. The emphasis must be on sensitive flexibility in the organization of the school program. Although no blueprint exists for choosing the right strategy, it is wise to remember that gifted children need to associate with other persons of similar ability and interests for at least some period of time (Coleman, 1995; Leyden, 1985; Del Giomo, 1977). Such peer interaction helps the gifted gain a realistic understanding of their own performance intellectual and otherwise.

Further recommendations go toward the provision for teachers of preservice training in dealing effectively with the gifted. In-service training programs in this area are also needed. Teachers of the gifted need to understand how important it is to develop power in their gifted students - the power to help them become independent learners. It is through appropriate teaching styles and good guidance in the use of thinking skills that the gifted are encouraged to "try out their intellectual wings" (Freeman, 1995, p. 179). The need for the teacher to provide all kinds of mental structures to foster the development of complex thinking should diminish as pupils develop and show their capability in handling these processes autonomously (Clarke, 1989, as cited in Span, 1995, p. 78).

Certainly, one must also realize that the responsibility to offer the best education for the gifted must be shared by the parents who should be wise enough to recognize the difference between pushing and intellectual stimulation. The latter may be achieved through the sharing of suitable experiences such as recreation, travel, museum and cultural visits, and library use.

In Malta, as in any other country, people need to join forces and strive together for excellence in education. The provision of an empowering and creative learning environment is for all students. All children are entitled to an education that will enable them to fully develop all of their diverse abilities. The gifted are no exception. At the same time, one must realize that "waste of human potential is tragic for the community, for the world, but especially for the child" (George, 1995, p. ix). It is also important to stress that the quality of life tomorrow is locked in the potential of today's children. The appropriate education is the key that, alone, unlocks their gifts. 


\section{Implications for Practice and Future Research}

Malta seems to understand that gifted students are students who have special needs. In order to create a better quality of life for everyone, society simply cannot ignore the gifted and the fact that gifted students do not just make it on their own. Educators need to respect the differences between students and they also need to be trained further along this line to improve their ability to offer their students the right experiences.

Although the start of the implementation of the new NMC in September 2000 was a step in the right direction, more longitudinal research is still needed. It will be important to assess how much the students have gained out of the new approach to schooling that was envisioned. Such research will help provide an ever-evolving process of education with a curriculum that is as it should be, not static and transmitted, but dynamic and interactive.

\section{References}

An on-going leaming process. (1997, October 12). The Malta Independent, p. 27.

Bezzina, C. (1997). Teacher empowerment: The way forward for quality improvement. Education 2000, 2, 16-17.

Borg, M., \& Falzon, J. M. (1989). Streaming in Malta: Current practices and future prospects. Education: The Journal of the Faculty of Education, 3 (3), 15-20.

Buhagiar, M. A. (1998). The discontinuation of the comprehensive system in Malta. The Teacher Quarterly 2$3 / 98(71), 6-10$.

Cassar, J. (1999, May 29). Teaching kids how to think. The Malta Independent, p. 8.

Coleman, L. J. (1995). The power of specialized educational environments in the development of giftedness: The need for research on social context. Gifted Child Quarterly. 39. 171-176.

Consultative Committee on Education. (1995). Tomorrow's schools: Developing effective learning cultures. Malta: Ministry of Education.

Creativity and thinking skills. (1997, August 28). The Times, p. 20.

Darmanin, M. (1996). Closing options, opening opportunities. In F. Ventura (Ed.), Secondary Education in Malta: Challenges and Opportunities (pp. 77-88). Valletta, Malta: MUT.

de Bono, E. (1992). Teach your child how to think London: Penguin Group.

Del Giorno, B. J. (1977). ReTAL as a model for developing critical and divergent thinking in gifted and talented students of science. Gifled Child Quarterly 21, 58-65.

Edward de Bono fires children's imagination. (1999, May 27).
The Times, p. 26.

Farrugia, C. (1991). The National Minimum Curriculum: A professional challenge. In C. Farmugia (Ed.), A National Minimum Curriculum for Malta (pp. 17-26). Malta: University of Malta, Foundation for International Studies, The Ministry of Education.

Freeman, J. (1992). Recent developments for the highly able in Britain. In F. J. Mönks, M.W. Katzko, \& H.W. van Boxtel (Eds.), Education of the gifted in Europe: Theoretical and research issues (pp. 58-70). Amsterdam, Netherlands: Swets and Zeitlinger B.V.

Freeman, J. (1995). Towards a policy for actualising talent. In J. Freeman, P. Span, \& H. Wagner (Eds.), Actualising talent : A lifelong challenge (pp. 174-192). London \& New York: Cassell.

George, D. (1995). The challenge of the able child. Great Britain: David Fulton.

Giordmaina, J. (1997, September 7). The teaching of thinking. The Sunday Times, p. 33.

Hirst, P. H. (1989). Ethical considerations in selecting and streaming in education. Education: The Journal of the Faculty of Education 3 (3), 2-8.

Johnston, J. (1997a). Malta takes the Let Me Learn initiative to a higher level. Retrieved December 18, 1977, from the World Wide Web: http://www.letmelearn.org/malta97.html

Johnston, J. (1997b). Let Me Learn. Retrieved December 18, 1977, from the World Wide Web: http://www.letmelearn.org

Leyden, S. (1985). Helping the child of exceptional ability. Great Britain: Croom Helm.

Maclure, S. (1991). Introduction: An overview. In S. Maclure \& P. Davies (Eds.), Learning to think: Thinking to learn. Oxford, U.K.: Pergamon Press.

Making the most of students' learning abilities. (2000, March 10). The Times, p. 25.

Malta Government. (1989). Education Act, 1988, National Minimum Curriculum Regulations. Valletta, Malta: Government Printing Press.

Maltese teachers praised by visiting professor. $(1998$, October 5). The Malta Independent, p. 40.

Mifsud, C. (1997). Pupil profiling. Education 2000, 1, 20-21.

Mifsud, J. (1991). Keeping a balance between the cognitive, the motor and socio-affective domains. In C. Farrugia (Ed), A National Minimum Curriculum for Malta (pp. 50-56). Malta: University of Malta, Foundation for International Studies, The Ministry of Education.

Ministry of Education (2000). Letter of the Minister of Education to the educators of Malta (14 th January 2000).

Montgomery, D. (1996). Educating the able. London: Casseli.

Musumeci, M. (1981) The Special Science Examination 1978: A Study. Unpublished B.A. (Educ.) dissertation, University of Malta.

National Minimum Curriculum NMC. (1999). Creating the future together. Malta: Ministry of Education.

Nisbet, J. (1991). Projects, theories and methods: The international scene. In M. J. Coles \& W.D. Robinson (Eds.), Teaching thinking. A survey of programmes in education. London: Bristol Classical Press.

Primary Level National Minimum Curriculum, Legal Notice 73 
(1989).

Reid, 1. (1986). The sociology of school and education. London: Fontana Press.

Renzulli, J. S. (1986). The three-ring conception of giftedness: A developmental model for creative productivity. In R. J. Stemberg \& J. E. Davidson (Eds.), Conceptions of Giftedness (pp. 53-92). Cambridge, U.K.: Cambridge University Press.

Secondary Level National Minimum Curriculum, Legal Notice 103 (1990).

Span, P. (1995). Self-regulated learning by talented children. In J. Freeman, P. Span, \& H. Wagner (Eds.), Actualising talents: A lifelong challenge. London: Cassell.

Sultana, R. G. (1989). Streaming: A sociological perspective. Education: The Journal of the Faculty of Education 3 (3), 914.

Sultana, R. G. (1996). Underachievement: Are students failing school or are our schools failing students? In F. Ventura (Ed.), Secondary education in Malta: Challenges and opportunities. Malta: MUT.

Sultana, R. G (1997). Education as struggle. In R. G. Sultana, Inside/Outside Schools: Towards a Critical Sociology of Education in Malta (pp. 55-85). Malta: Publisher Enterprises Group Ltd.

Tannenbaum, A. J. (1986). Giftedness: A psychological approach. In R. J. Stemberg \& J. E. Davidson (Eds.), Conceptions of giftedness (pp. 21-52). Cambridge, U.K.: Cambridge University Press.

The Newsletter of the Education Division (1997). That all children leam how to read and write. Eduforum 7. 1-8, Malta: Education Division.

University Information Booklet. (1994). The Matriculation Certificate Examination Commencing May 1996. Malta: University of Malta.

Ventura, F. (1996). Secondary education in Malta: Back to the future. In F. Ventura (Ed.), Secondary education in Malta: challenges and opportunities (pp. 165-180). Malta: MUT.

Wain, K. (1994). Secondary education and research in Malta: An overview. In P. Heywood, K. Wain, \& J. Calleja (Eds.), Research into secondary school curricula (Report of the Educational Research Workshop held in Malta, 6-9 October 1992, pp. 45-55). Lisse: Swets and Zeitlinger.

Wanna be creative! (1997, September 2). The People, p. 4.

Young, P., \& Tyre, C. (1992) Gifted or able?: Realizing children's potential. U.K.: Open University Press.

Zammit Ciantar, J. (1993). Education in Malta - A handbook. Malta: Ministry of Education and Human Resources. 